\title{
Cover crops on the development of beggar's-tick ${ }^{1}$
}

\author{
Leandro Pereira Pacheco ${ }^{2}$, Marinete Martins de Sousa Monteiro ${ }^{3}$, \\ Fabiano André Petter ${ }^{4}$, Francisco de Alcântara Neto ${ }^{5}$, Fernandes Antônio de Almeida ${ }^{3}$
}

\begin{abstract}
RESUMO
Plantas de cobertura no desenvolvimento de picão-preto

Estudos para identificar espécies de cobertura com potencial para o plantio direto e as quantidades mínimas de biomassa requeridas para reduzir a emergência e desenvolvimento de plantas daninhas em lavouras de cereais podem representar importante ferramenta no manejo integrado de plantas daninhas. Assim, este trabalho objetivou avaliar a inibição da emergência e do crescimento de plantas de Bidens pilosa, utilizando-se diferentes níveis de fitomassa de plantas de cobertura sobre a superfície do solo. O experimento foi conduzido em casa-de-vegetação, de dezembro de 2011 a março de 2012, em Bom Jesus (PI), sendo utilizado delineamento experimental de blocos casualizados, com quatro repetições, em esquema fatorial $(6 \times 5)+1$, constituído por seis plantas de cobertura e cinco níveis de fitomassa sobre o solo, mais um tratamento controle, sem cobertura de solo. As espécies avaliadas foram Pennisetum glaucum (cultivares ADR 7010 e ADR 300), Crotalaria ochroleuca, Urochloa ruziziensis (syn. Brachiaria ruziziensis), Crambe abyssinica e Fagopyrum tataricum, em cinco níveis de fitomassa correspondentes a 4,0 tha $^{-1}$; 8,0 tha $^{-1} ; 12,0$ t ha $^{-1} ; 16,0$ tha $^{-1} ; \mathrm{e} 20,0$ tha $^{-1}$. Urochloa ruziziensis $\mathrm{e}$ Fagopyrum tataricum se destacaram no controle de B. pilosa, sendo que 4,0 tha-1 de fitomassa seca destas espécies foram suficientes para promover redução no número total de plantas emergidas, índice de velocidade de germinação, fitomassa seca da parte aérea, área foliar, fitomassa seca de raízes e volume de raízes de $B$. pilosa.
\end{abstract}

PALAVRAS-CHAVE: Bidens pilosa L.; Urochloa ruziziensis (R. Germ. \& Evrard) Morrone \& Zuloaga; Crotalaria ochroleuca G. Don.; Crambe abyssinica Hochst; Fagopyrum tataricum Gaertn.

\section{INTRODUCTION}

The Pauí Brazilian Savannah is located in the south of the Piauí State, which stands for high grain

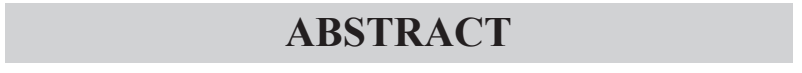

Studies to identify potential cover crops species for the no-till system and minimal amounts of biomass required to reduce the emergence and development of weeds in cereal crop areas may represent an important tool in the integrated weed management. Thus, this study aimed at evaluating the inhibition of the emergence and growth of Bidens pilosa plants, using different cover crops biomass levels on the soil surface. The experiment was carried out in a greenhouse located in Bom Jesus, Piauí State, Brazil, from December 2011 to March 2012 , in a randomized experimental blocks design with four replications, in a $(5 \times 6)+1$ factorial scheme, consisting of six cover crop species and five biomass levels on the soil surface, plus a control with no soil cover. The species evaluated were Pennisetum glaucum (ADR 7010 and ADR 300 cultivars), Crotalaria ochroleuca, Urochloa ruziziensis (syn. Brachiaria ruziziensis), Crambe abyssinica and Fagopyrum tataricum, at five biomass levels corresponding to $4.0 \mathrm{t} \mathrm{ha}^{-1}, 8.0 \mathrm{t} \mathrm{ha}^{-1}$, $12.0 \mathrm{t} \mathrm{ha}^{-1}, 16.0 \mathrm{t} \mathrm{ha}^{-1}$ and $20.0 \mathrm{t} \mathrm{ha}^{-1}$. Urochloa ruziziensis and Fagopyrum tataricum were considered the best ones for controlling $B$. pilosa, with $4.0 \mathrm{t} \mathrm{ha}^{-1}$ of their biomass being sufficient to reduce the total number of emerged plants, germination speed index, shoot dry biomass, leaf area, root dry biomass and root volume of B. pilosa.

KEY-WORDS: Bidens pilosa L.; Urochloa ruziziensis (R. Germ. \& Evrard) Morrone \& Zuloaga; Crotalaria ochroleuca G. Don.; Crambe abyssinica Hochst; Fagopyrum tataricum Gaertn.

yields, in Brazil. In the 2011/2012 crop season, its average yield for rice and soybean were respectively $1,957 \mathrm{~kg} \mathrm{ha}^{-1}$ and $3,000 \mathrm{~kg} \mathrm{ha}^{-1}$, representing an increase of $0.6 \%$ and $6.1 \%$, when compared to the

1. Article received in Oct./2012 and accepted for publication in May/2013 (Registration number: PAT 20665).

2. Universidade Federal de Mato Grosso (UFMT), Departamento de Engenharia Agrícola, Rondonópolis, MT, Brazil. E-mail: leandroppacheco@gmail.com.

3. Universidade Federal do Piauí (UFPI), Campus Professora Cinobelina Elvas, Bom Jesus, PI, Brazil. E-mails: marinettmartins@hotmail.com, fernandes@ufpi.edu.br.

4. Universidade Federal de Mato Grosso (UFMT), Instituto de Ciências Agrárias e Ambientais, Sinop, MT, Brazil. E-mail: fabianopetter@brturbo.com.br.

5. Universidade Federal do Piauí (UFPI), Campus Ministro Petrônio Portella, Departamento de Fitotecnia, Teresina, PI, Brazil. E-mail: fneto@ufpi.edu.br. 
previous crop season. However, the maize yield reached $1,760 \mathrm{~kg} \mathrm{ha}^{-1}$, with a reduction of $12.7 \%$ (Conab 2012).

The increase in demand for grains and the need for mitigation of environmental impacts in agriculture have become very important to the development of sustainable production techniques that are more efficient for increasing yield. When considering that the chemical weed control is the main technique used by producers, it is necessary to study sustainable and economically viable techniques that can be incorporated in the integrated weed management, such as the benefits of biomass cover crops on the soil surface, in no-till systems (Pacheco et al. 2009).

Bidens pilosa, also known as beggar's-tick, is a herbaceous plant native from the tropical America, with a high incidence in South America and other tropical areas of the world. In Brazil, it occurs almost all over the country, being regarded as one of the most important weeds in annual and perennial crops (Kissmann \& Groth 1992). The weed belongs to the Compositae family, and "Bidens" stands for "two teeth", referring to the two projections of the achene, while "pilosa" refers to the presence of hairs on the bracts (Kissmann \& Groth 1992).

It is an aggressive species, which competes with crops by water, nutrients and solar radiation, besides serving as a host for pests and diseases, causing significant yield reduction. Furthermore, this species presents a high capacity to acquire resistance or tolerance to herbicides, reproduction by seed, fast growth and can be found throughout the year, with high infestation rates (Kissmann 1997).

According to Chivinge (1996), the adequate temperature range for the beggar's-tick germination is $20-35^{\circ} \mathrm{C}$, with a maximum rate of $70 \%$ occurring at $25^{\circ} \mathrm{C}$. Klein \& Fellipe (1991) reported that the beggar's-tick germination can occur in the absence of light, whereas Amaral \& Takaki (1998), evaluating the achenes structure of this species, observed that integument warty achenes presented dormancy and sensitivity to light, while achenes without ornaments showed no dormancy or sensitivity to light, during the germination process.

Biomass yield and soil cover can assist in controlling weeds, with the aid of physical, chemical and microbiological methods, besides allelopathy (Pacheco et al. 2009). The physical effect of mulch contributes to shade the soil, inhibiting seed germination and weed infestation, thus enabling a crop development with less initial competition (Queiroz et al. 2010).

The allelopathic effects from the biomass decomposition or root exudation of allelochemicals may exert deleterious effects on seed germination, or interfere in any development process, slowing or delaying growth, or even leading to plant death (Alvarenga et al. 2001). However, the response for the use of cover crops on weeds germination depends upon the amount and distribution of waste, besides its allelopathic potential (Chauhan et al. 2012).

Pacheco et al. (2009) reported satisfactory weed control, when they used at least $7,000 \mathrm{~kg} \mathrm{ha}^{-1}$ of cover crop biomass on the soil surface. In their study, Uroclhoa sp. stood out for reducing weeds emergence and growth. Correia et al. (2006) observed reductions in the weeds emergence and growth when $3,000 \mathrm{~kg} \mathrm{ha}^{-1}$ of biomass (Uroclhoa spp. and Sorghum bicolor) were used.

Studies are necessary to identify potential cover crops and minimum amounts of biomass required to reduce weeds emergence and growth in cereal crop areas. Thus, this study aimed at evaluating the inhibition of Bidens pilosa emergence and growth, by using different biomass cover crops levels on the soil surface.

\section{MATERIAL AND METHODS}

The experiment was carried out in a greenhouse of the Universidade Federal do Piauí, located in Bom Jesus, Piauí State, Brazil, from December 2011 to March 2012. The experimental design was randomized blocks, in a $(6 \times 5)+1$ factorial scheme, consisting of six cover crops and five biomass levels (dry biomass) on the soil surface, plus a treatment with no cover plants (fallow ground), with four replications, totaling 124 experimental plots.

The cover crops tested in this study were the pearl millet cv. ADR300 (Pennisetum glaucum), millet cv. ADR 7010 (Pennisetum glaucum), crotalaria (Crotalaria ocroleuca), buckwheat (Fagopyrum tataricum), crambe (Crambe abyssinica) and urochloa (Urochloa ruziziensis). The amounts of dry biomass per plot were $0.0 \mathrm{~g} \mathrm{pot}^{-1}, 38.5 \mathrm{~g} \mathrm{pot}^{-1}$, $76.9 \mathrm{~g} \mathrm{pot}^{-1}, 115.5 \mathrm{~g} \mathrm{pot}^{-1}, 154.0 \mathrm{~g} \mathrm{pot}^{-1}$ and $192,5 \mathrm{~g} \mathrm{pot}^{-1}$, corresponding to $0.0 \mathrm{t} \mathrm{ha}^{-1}, 4.0 \mathrm{t} \mathrm{ha}^{-1}, 8.0 \mathrm{t} \mathrm{ha}^{-1}$, 12.0 $\mathrm{t} \mathrm{ha}^{-1}, 16.0 \mathrm{t} \mathrm{ha}^{-1}$ and $20 \mathrm{t} \mathrm{ha}^{-1}$.

Substrate samples from the $40.0-60.0 \mathrm{~cm}$ layer of a dystrophic Oxisol of each experimental plot 
were distributed in pots $\left(8.0 \mathrm{dm}^{3}\right)$ with diameter of $35.0 \mathrm{~cm}$. This depth was selected in order to avoid the weeds seed bank present in the upper soil layers. The soil was prepared to achieve a base saturation of $50 \%$ and fertilized with NPK (10:20:20), at the rate of $0.4 \mathrm{~g} \mathrm{dm}^{-1}$ of soil, corresponding to $800.0 \mathrm{~kg} \mathrm{ha}^{-1}$. Thirty Bidens pilosa seeds were randomly sown per pot and covered with a layer of around $1.0 \mathrm{~cm}$ of soil. Fresh plant covering was added to the soil surface in amounts corresponding to different treatments (0.0 tha ${ }^{-1}, 4.0$ tha $^{-1}, 8.0$ tha $^{-1}, 16.0$ tha $^{-1}$ and 20.0 tha $^{-1}$; dry weight). The plant biomass was collected and fractionated at the day that the experiment took place, in order to avoid a possible allelochemicals loss.

To obtain the biomass, the cover crops were manually sown and grown in $5.0 \mathrm{~m}^{2}$ plots, and shoots were collected when they reached the reproductive stage. Plant residues were segmented into sections of about $2.0 \mathrm{~cm}$ and $3.0 \mathrm{~cm}$, weighed and adjusted to a dry basis, after staying in an oven at $60^{\circ} \mathrm{C}$, for 72 hours or until reaching constant weight. The wet material was adjusted according to the intended dry matter per hectare, being subsequently homogenized and kept on the soil surface (pots), as treatments. The irrigation was performed daily as needed.

The variables evaluated were: total number of emerged plants (TNEP), germination speed index (GSI), leaf area (LA), root volume (RV) and shoot (SDB) and root dry biomass (RDB). The GSI was calculated by using the equation described by Maguire (1962): GSI [N1 / $1+(\mathrm{N} 2-\mathrm{N} 1) / 2+(\mathrm{N} 3-$ $\mathrm{N} 2) / 3+\ldots .(\mathrm{Nn}, \mathrm{Nn}-1) / \mathrm{n}]$, with N1, N2, N3... Nn corresponding to the number of emerged seedlings and $1,2,3 \ldots \mathrm{n}$ to the number of days after sowing (DAS).

At 50 DAS, the leaf area was determined with the aid of a LI-3100 Area Meter equipment (LI-COR Inc. Lincoln, NE, USA), when most weeds reached the pre-flowering stage, with leaves being detached from the stem to carry out the measurement $\left(\mathrm{cm}^{2}\right.$ pot $\left.^{-1}\right)$. Also at 50 DAS, roots were separated from shoots, washed in water and immediately subjected to root volume (RV) measurement $\left(\mathrm{cm}^{3}\right.$ pot $\left.^{-1}\right)$, by using the beaker method (Basso 1999). Both the shoot and root were dried in an oven at $60^{\circ} \mathrm{C}$, until reaching constant weight, to obtain the dry biomass.

These procedures were performed by using the variance analysis (Anova), with the aid of the Sisvar 4.2 software, while the regression analysis was conducted by using the Sigma Plot 10.1 software.

\section{RESULTS AND DISCUSSION}

A significant interaction was observed between cover crop treatments and the amount of biomass for total number of emerged plants (TNEP) and germination speed index (GSI). All cover crops tested were effective to reduce these variables, especially Urochloa ruziziensis and Fagopyrum tataricum, which promoted the largest reductions in almost all the amounts of biomass studied (Table 1). These results can be explained by the physical control provided by the presence of biomass on the soil surface (Severino \& Christofoletti 2001), which modify and reduce the quality of the light required to stimulate germination (Theisen et al. 2000). It also promotes a physical barrier that can affect the reserve material in seedlings, during their early development, what may be confirmed by the significant reduction in the GSI (higher than 50\%), when compared to the control treatment without cover crops. Similar results were observed by Correia et al. (2006), with a significant control of Bidens pilosa by using $3.0 \mathrm{t} \mathrm{ha}^{-1}$ of cover crop biomass.

The allelopathy process, which releases natural substances that can reduce germination and delay the early development of seedlings, during the decomposition of biomass on the soil surface (Trezzi \& Vidal 2004), may contribute to the control of Bidens pilosa. However, it was observed, in the present study, that the potential of allelopathic cover crops differ according to the plant species or even among cultivars. This process was most evident for treatments with $F$. tataricum, at a initial amount of biomass, which showed lower coverage of the soil surface, besides providing reductions higher than $75 \%$ in the TNEP and GSI, at $4.0 \mathrm{t} \mathrm{ha}^{-1}$.

Silva et al. (2011), analyzing the allelopathy of Camelina sativa (Brassicaceae) on the germination and initial development of Bidens pilosa, verified the occurrence of inhibitory activity, represented by the delay in seed germination, resulting in a decrease of the average germination speed with increasing concentrations of different aqueous extracts. Severino \& Christofoletti (2001) observed a reduction in the Bidens pilosa emergence rate, depending on the availability of cover crops on the soil.

P. glaucum presented a biomass geometry that provides low soil coverage, due to the high leaf/stem ratio and may be considered an undesirable trait, when the purpose is covering the soil. However, although 
Table 1. Total number of emerged plants and germination speed index of Bidens pilosa, according to the cover crop and amount of biomass on the soil surface (Bom Jesus, PI, 2012).

\begin{tabular}{|c|c|c|c|c|c|c|}
\hline \multirow{2}{*}{ Cover crop } & \multicolumn{6}{|c|}{ Amount of biomass $\left(\mathrm{t} \mathrm{ha}^{-1}\right)$} \\
\hline & 0 & 4 & 8 & 12 & 16 & 20 \\
\hline & \multicolumn{6}{|c|}{ Total number of emerged plants pot ${ }^{1}$} \\
\hline P. glaucum ADR 7010 & $8,6 \mathrm{~A}$ & $3,3 \mathrm{~A}$ & $5,0 \mathrm{D}$ & $4,0 \mathrm{C}$ & $3,0 \mathrm{C}$ & $2,3 \mathrm{~B}$ \\
\hline C. ocroleuca & $8,6 \mathrm{~A}$ & $5,3 \mathrm{~B}$ & $4,0 \mathrm{CD}$ & $1,0 \mathrm{~A}$ & $1,0 \mathrm{~A}$ & $1,0 \mathrm{AB}$ \\
\hline B. ruziziensis & $8,6 \mathrm{~A}$ & $3,3 \mathrm{~A}$ & $1,0 \mathrm{~A}$ & $1,6 \mathrm{AB}$ & $1,6 \mathrm{AB}$ & $0,0 \mathrm{~A}$ \\
\hline C. abyssinica & $8,6 \mathrm{~A}$ & $6,0 \mathrm{~B}$ & $3,0 \mathrm{BC}$ & $3,0 \mathrm{BC}$ & $1,0 \mathrm{~A}$ & $0,6 \mathrm{AB}$ \\
\hline P. glaucum ADR 300 & $8,6 \mathrm{~A}$ & $3,3 \mathrm{~A}$ & $4,3 \mathrm{CD}$ & $1,6 \mathrm{AB}$ & $1,0 \mathrm{~A}$ & $1,3 \mathrm{AB}$ \\
\hline F. tataricum & $8,6 \mathrm{~A}$ & $2,3 \mathrm{~A}$ & $1,6 \mathrm{AB}$ & $1,3 \mathrm{AB}$ & $2,6 \mathrm{AB}$ & $1,3 \mathrm{AB}$ \\
\hline \multirow[t]{2}{*}{$\mathrm{CV}(\%)$} & \multicolumn{6}{|c|}{21,22} \\
\hline & \multicolumn{6}{|c|}{ Germination speed index } \\
\hline P. glaucum ADR 7010 & $1,37 \mathrm{~A}$ & $0,29 \mathrm{~A}$ & $0,63 \mathrm{C}$ & $0,24 \mathrm{~A}$ & $0,22 \mathrm{AB}$ & $0,11 \mathrm{~A}$ \\
\hline C. ocroleuca & $1,37 \mathrm{~A}$ & $0,88 \mathrm{C}$ & $0,42 \mathrm{BC}$ & $0,14 \mathrm{~A}$ & $0,02 \mathrm{~A}$ & $0,04 \mathrm{~A}$ \\
\hline B. ruziziensis & $1,37 \mathrm{~A}$ & $0,33 \mathrm{~A}$ & $0,25 \mathrm{AB}$ & $0,01 \mathrm{~A}$ & $0,13 \mathrm{~A}$ & $0,00 \mathrm{~A}$ \\
\hline C. abyssinica & $1,37 \mathrm{~A}$ & $0,65 \mathrm{BC}$ & $0,19 \mathrm{AB}$ & $0,13 \mathrm{~A}$ & $0,01 \mathrm{~A}$ & $0,01 \mathrm{~A}$ \\
\hline P. glaucum ADR 300 & $1,37 \mathrm{~A}$ & $0,45 \mathrm{AB}$ & $0,40 \mathrm{BC}$ & $0,17 \mathrm{~A}$ & $0,42 \mathrm{~B}$ & $0,18 \mathrm{~A}$ \\
\hline F. tataricum & $1,37 \mathrm{~A}$ & $0,35 \mathrm{~A}$ & $0,11 \mathrm{~A}$ & $0,09 \mathrm{~A}$ & $0,08 \mathrm{~A}$ & $0,05 \mathrm{~A}$ \\
\hline CV $(\%)$ & \multicolumn{6}{|c|}{26,96} \\
\hline
\end{tabular}

Means followed by the same letter, in the column, do not differ significantly by the Tukey test $(\mathrm{p} \leq 0.05)$.

not quantified, it was noted that the decomposition rate of its remaining biomass was lower, along with its high biomass yield capacity in the Brazilian Savannah (Pacheco et al. 2011), pointing out this species as a viable option for the integrated weed management. Correia et al. (2006) observed a potential use of the millet forage, starting at $3.0 \mathrm{t} \mathrm{ha}^{-1}$, for controlling $B$. pilosa in no-till systems.

$B$. ruziziensis showed to be an excellent soil cover, due to its ability to reduce the $B$. pilosa emergence, reaching full control when used at $20.0 \mathrm{tha}^{-1}$. Correia et al. (2006) observed a reduction of $85 \%$ in $B$. pilosa infestation, when $3.0 \mathrm{t} \mathrm{ha}^{-1}$ of $B$. brizantha biomass was used in no-till systems.

The cover crops presented an exponential decreasing tendency for the variables TNEP and GSI (Figure 1). These results indicate that other significant effects over the reduction of these variables occurred for the initial amount of biomass, as attested by the amount of biomass required to reduce in $50 \%$ the TNEP and by the fact that the GSI reached less than $5.0 \mathrm{t} \mathrm{ha}^{-1}$ of biomass, except for P. glaucum. These results reinforce the importance of the presence of biomass on the soil surface, when sowing annual crops in the integrated weed management. Erasmo et al. (2004) demonstrated the benefits of using biomass cover crops to control weeds within 60 days of desiccation, especially for Mucuna aterrima, and its effect as a physical and allelopathic barrier.
B. ruziziensis and $F$. tataricum treatments reduced the TNEP and GSI of B. pilosa (Figure 1), due to their high capacity to cover the soil and release allelochemicals, during the biomass decomposition.

The shoot dry biomass (SDB) and leaf area (LA) showed a significant interaction between cover crops and amounts of biomass (Table 1). The lowest SDB and LA for B. pilosa were observed when sown in the presence of B. ruziziensis and F. tataricum, what can be explained by the lower number of emerged plants and lower seedlings germination speed (Table 2).

The delay in seedling emergence, due to the presence of biomass on the soil surface, in the no-till system, was effective to prevent or delay the weed competition in the area, since the reduction in SDB and LA made weeds less competitive. Gimenes et al. (2011) demonstrated that $10.0 \mathrm{t} \mathrm{ha}^{-1}$ of Urochloa decumbens biomass, at 60 days after emergence, caused a reduction of more than $80 \%$ in the leaf area of Digitaria horizontalis and C. echinatus weeds.

The LA and SDB of cover crops decreased exponentially, proving the most significant reduction in the development of $B$. pilos $a$, when considered the initial amount of biomass (Figure 2). These results demonstrate that the amount of up to $8.0 \mathrm{t} \mathrm{ha}^{-1}$ of biomass was effective to reduce (more than $50 \%$ ) the values for these variables, in relation to the control, except for P. glaucum. Similar results were observed 

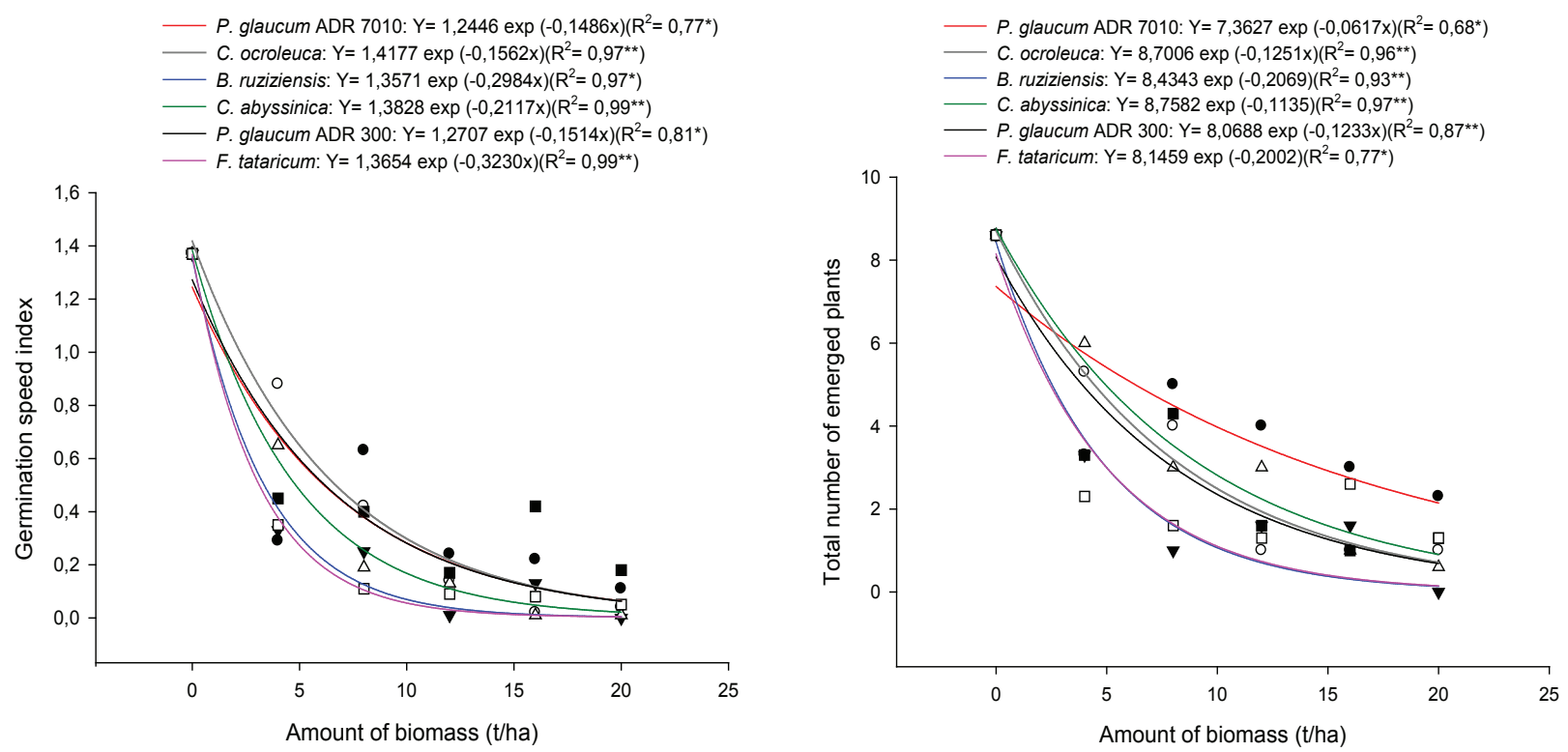

Figure 1. Germination speed index and total number of emerged plants of Bidens pilosa, according to the cover crop and amount of biomass. ${ }^{\text {ns }}, *$ and $* *$ : not significant and significant at $\mathrm{p} \leq 0.05$ and $\mathrm{p} \leq 0.1$, respectively (Bom Jesus, PI, 2012).

Table 2. Shoot dry biomass and leaf area of Bidens pilosa, at 50 days after sowing, according to the cover crop and amount of biomass on the soil surface (Bom Jesus, PI, 2012).

\begin{tabular}{|c|c|c|c|c|c|c|}
\hline \multirow{2}{*}{ Cover crop } & \multicolumn{6}{|c|}{ Amount of biomass $\left(\mathrm{t} \mathrm{ha}^{-1}\right)$} \\
\hline & 0 & 4 & 8 & 12 & 16 & 20 \\
\hline & \multicolumn{6}{|c|}{ Shoot dry biomass $\left(\mathrm{g} \mathrm{pot}^{-1}\right)$} \\
\hline P. glaucum ADR 7010 & $20,48 \mathrm{~A}$ & $11,16 \mathrm{C}$ & $16,30 \mathrm{D}$ & $4,44 \mathrm{C}$ & $2,10 \mathrm{~A}$ & $4,90 \mathrm{~B}$ \\
\hline C. ocroleuca & $20,48 \mathrm{~A}$ & $16,18 \mathrm{D}$ & $7,32 \mathrm{~B}$ & $4,34 \mathrm{C}$ & $0,82 \mathrm{~A}$ & $1,40 \mathrm{~A}$ \\
\hline B. ruziziensis & $20,48 \mathrm{~A}$ & $5,60 \mathrm{~A}$ & $9,73 \mathrm{C}$ & $0,40 \mathrm{~A}$ & $4,66 \mathrm{~B}$ & $0,00 \mathrm{~A}$ \\
\hline C. abyssinica & $20,48 \mathrm{~A}$ & $8,76 \mathrm{~B}$ & $4,73 \mathrm{~A}$ & $3,73 \mathrm{BC}$ & $0,16 \mathrm{~A}$ & $0,03 \mathrm{~A}$ \\
\hline P. glaucum ADR 300 & $20,48 \mathrm{~A}$ & $13,98 \mathrm{D}$ & $8,43 \mathrm{BC}$ & $5,63 \mathrm{C}$ & $2,20 \mathrm{~A}$ & $5,33 \mathrm{~B}$ \\
\hline F. tataricum & $20,48 \mathrm{~A}$ & $6,38 \mathrm{~A}$ & $2,46 \mathrm{~A}$ & $1,73 \mathrm{AB}$ & $1,22 \mathrm{~A}$ & $0,80 \mathrm{~A}$ \\
\hline \multirow[t]{2}{*}{ CV $(\%)$} & \multicolumn{6}{|c|}{12,8} \\
\hline & \multicolumn{6}{|c|}{ Leaf area $\left(\mathrm{cm}^{2}\right.$ pot $\left.^{1}\right)$} \\
\hline P. glaucum ADR 7010 & $2.876,00 \mathrm{~A}$ & $1.846,33 \mathrm{~B}$ & $2.349,00 \mathrm{E}$ & $991,00 \mathrm{D}$ & 408,63 BC & $689,66 \mathrm{~B}$ \\
\hline C. ocroleuca & $2.876,00 \mathrm{~A}$ & $2.322,66 \mathrm{C}$ & $1.169,33 \mathrm{C}$ & $580,66 \mathrm{BC}$ & $102,66 \mathrm{AB}$ & $11,33 \mathrm{~A}$ \\
\hline B. ruziziensis & $2.876,00 \mathrm{~A}$ & $827,00 \mathrm{~A}$ & $841,33 \mathrm{~B}$ & $85,66 \mathrm{~A}$ & $935,00 \mathrm{D}$ & $0,00 \mathrm{~A}$ \\
\hline C. abyssinica & $2.876,00 \mathrm{~A}$ & $591,66 \mathrm{~A}$ & $1.330,00 \mathrm{C}$ & $739,00 \mathrm{CD}$ & $15,66 \mathrm{~A}$ & $21,00 \mathrm{~A}$ \\
\hline P. glaucum ADR 300 & $2.876,00 \mathrm{~A}$ & $1.719,33 \mathrm{~B}$ & $1.644,66 \mathrm{D}$ & $869,33 \mathrm{CD}$ & $511,66 \mathrm{C}$ & $747,66 \mathrm{~B}$ \\
\hline F. tataricum & $2.876,00 \mathrm{~A}$ & $792,33 \mathrm{~A}$ & $426,33 \mathrm{~A}$ & $331,33 \mathrm{AB}$ & $633,00 \mathrm{CD}$ & $197,66 \mathrm{~A}$ \\
\hline $\mathrm{CV}(\%)$ & \multicolumn{6}{|c|}{11,33} \\
\hline
\end{tabular}

Means followed by the same letter, in the column, do not differ significantly by the Tukey test ( $\mathrm{p} \leq 0.05)$.

by Moraes et al. (2010), with a significant reduction in the SDB and LA of Bidens pilosa, when treated with $4.0 \mathrm{t} \mathrm{ha}^{-1}$ of ryegrass biomass (Lolium multiflorium) on the soil surface. These results indicate the potential use of these cover crops as a tool for the integrated weed management in no-till system.

The variables root system, root dry biomass (RDB) and root volume (RV) showed significant interaction between cover crops and amounts of biomass (Table 1). These results indicate that the B. ruziziensis, F. tataricum and C. abyssinica species provided greater reductions in the B. pilosa root growth, what can be explained by the decrease in the number of germinated plants, delay in emergence promoted by physical barrier and release of allelopathic substances by cover crops (Table 3 ). 

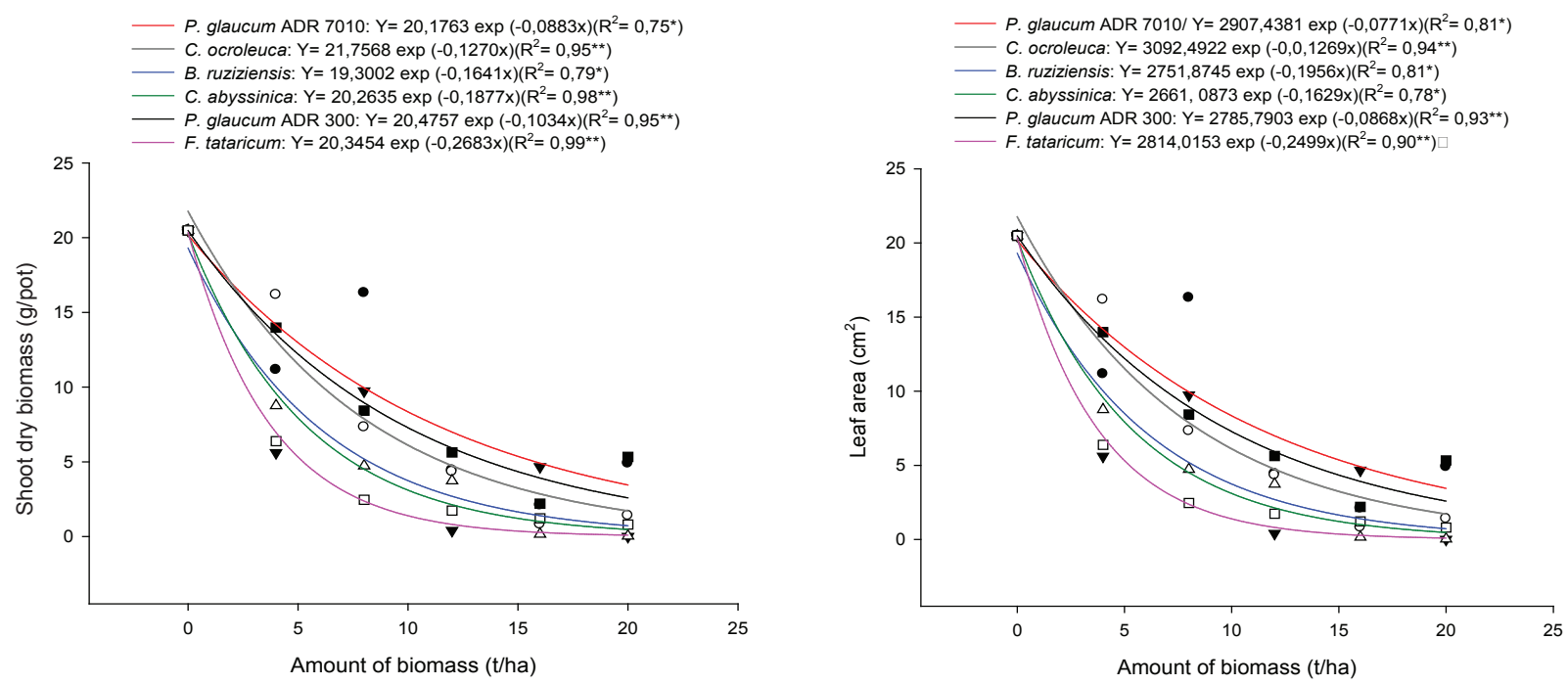

Figure 2. Shoot dry biomass and leaf area of Bidens pilosa, according to the cover crop and amount of biomass. ${ }^{\text {ns }},{ }^{*}$ and $* *$ : not significant and significant at $\mathrm{p} \leq 0.05$ and $\mathrm{p} \leq 0.1$, respectively (Bom Jesus, PI, 2012).

Table 3. Root dry biomass and root volume of Bidens pilosa, at 50 days after sowing, according to the cover crop and amount of biomass on the soil surface (Bom Jesus, PI, 2012).

\begin{tabular}{|c|c|c|c|c|c|c|}
\hline \multirow{2}{*}{ Cover crop } & \multicolumn{6}{|c|}{ Amount of biomass $\left(\mathrm{t} \mathrm{ha}^{-1}\right)$} \\
\hline & 0 & 4 & 8 & 12 & 16 & 20 \\
\hline & \multicolumn{6}{|c|}{ Root dry biomass $\left(g\right.$ pot $\left.^{-1}\right)$} \\
\hline P. glaucum ADR 7010 & $4,78 \mathrm{~A}$ & $2,10 \mathrm{~A}$ & $4,09 \mathrm{~B}$ & $1,65 \mathrm{~B}$ & $0,70 \mathrm{~A}$ & $1,16 \mathrm{~A}$ \\
\hline C. ocroleuca & $4,78 \mathrm{~A}$ & $5,85 \mathrm{C}$ & $2,20 \mathrm{~A}$ & $1,73 \mathrm{~B}$ & $0,30 \mathrm{~A}$ & $0,14 \mathrm{~A}$ \\
\hline B. ruziziensis & $4,78 \mathrm{~A}$ & $2,34 \mathrm{~A}$ & $2,07 \mathrm{~A}$ & $0,23 \mathrm{~A}$ & $1,25 \mathrm{~A}$ & $0,00 \mathrm{~A}$ \\
\hline C. abyssinica & $4,78 \mathrm{~A}$ & $1,16 \mathrm{~A}$ & $1,06 \mathrm{~A}$ & $1,32 \mathrm{AB}$ & $0,68 \mathrm{~A}$ & $0,01 \mathrm{~A}$ \\
\hline P. glaucum ADR 300 & $4,78 \mathrm{~A}$ & $3,73 \mathrm{~B}$ & $3,80 \mathrm{~B}$ & $1,18 \mathrm{AB}$ & $1,02 \mathrm{~A}$ & $1,16 \mathrm{~A}$ \\
\hline F. tataricum & $4,78 \mathrm{~A}$ & $1,83 \mathrm{~A}$ & $1,14 \mathrm{~A}$ & $0,71 \mathrm{AB}$ & $1,30 \mathrm{~A}$ & $0,10 \mathrm{~A}$ \\
\hline \multirow[t]{2}{*}{$\mathrm{CV}(\%)$} & \multicolumn{6}{|c|}{25,19} \\
\hline & \multicolumn{6}{|c|}{ Root volume $\left(\mathrm{cm}^{3}\right.$ pot $\left.^{-1}\right)$} \\
\hline P. glaucum ADR 7010 & $61,33 \mathrm{~A}$ & $27,66 \mathrm{BC}$ & $40,00 \mathrm{C}$ & $26,33 \mathrm{C}$ & $11,40 \mathrm{AB}$ & $10,16 \mathrm{~A}$ \\
\hline C. ocroleuca & $61,33 \mathrm{~A}$ & $56,66 \mathrm{D}$ & $25,33 \mathrm{~B}$ & $17,33 \mathrm{BC}$ & $2,10 \mathrm{AB}$ & $1,30 \mathrm{~A}$ \\
\hline B. ruziziensis & $61,33 \mathrm{~A}$ & $15,33 \mathrm{~A}$ & $21,00 \mathrm{AB}$ & $1,90 \mathrm{~A}$ & $23,33 \mathrm{C}$ & $0,00 \mathrm{~A}$ \\
\hline C. abyssinica & $61,33 \mathrm{~A}$ & $26,00 \mathrm{AB}$ & $16,53 \mathrm{AB}$ & $15,66 \mathrm{BC}$ & $0,83 \mathrm{~A}$ & $0,10 \mathrm{~A}$ \\
\hline P. glaucum ADR 300 & $61,33 \mathrm{~A}$ & $39,00 \mathrm{C}$ & $27,66 \mathrm{~B}$ & $13,83 \mathrm{~B}$ & $5,33 \mathrm{AB}$ & $11,33 \mathrm{~A}$ \\
\hline F. tataricum & $61,33 \mathrm{~A}$ & $29,33 \mathrm{BC}$ & $11,76 \mathrm{~A}$ & $10,33 \mathrm{AB}$ & $13,33 \mathrm{BC}$ & $8,33 \mathrm{~A}$ \\
\hline $\mathrm{CV}(\%)$ & \multicolumn{6}{|c|}{20,2} \\
\hline
\end{tabular}

Means followed by the same letter, in the column, do not differ significantly by the Tukey test $(\mathrm{p} \leq 0.05)$.

Although $C$. abyssinica was not efficient to reduce shoot growth, the $B$. pilosa root system was severely affected by the presence of its biomass. Moraes et al. (2010), studying the use of canola (Brassica napus), radish (Raphanus sativus), clover (Trifolium vesiculosum) and ryegrass (Lolium multiflorum), observed that in addition to inhibiting the emergence, growth and development of Bidens pilosa, the weed root system was also reduced by increasing the amount of biomass of those species on the soil surface.

C. ocroleuca showed less satisfactory results for controlling $B$. pilosa, since the most significant effects for reducing the TNEP, GSI, SDB, LA, $\mathrm{RDB}$ and RV with this species were observed from $8.0 \mathrm{t} \mathrm{ha}^{-1}$. Although the plant residues of this species have been suitable for promoting satisfactory soil coverage, it was noted that the thickness of the thin 

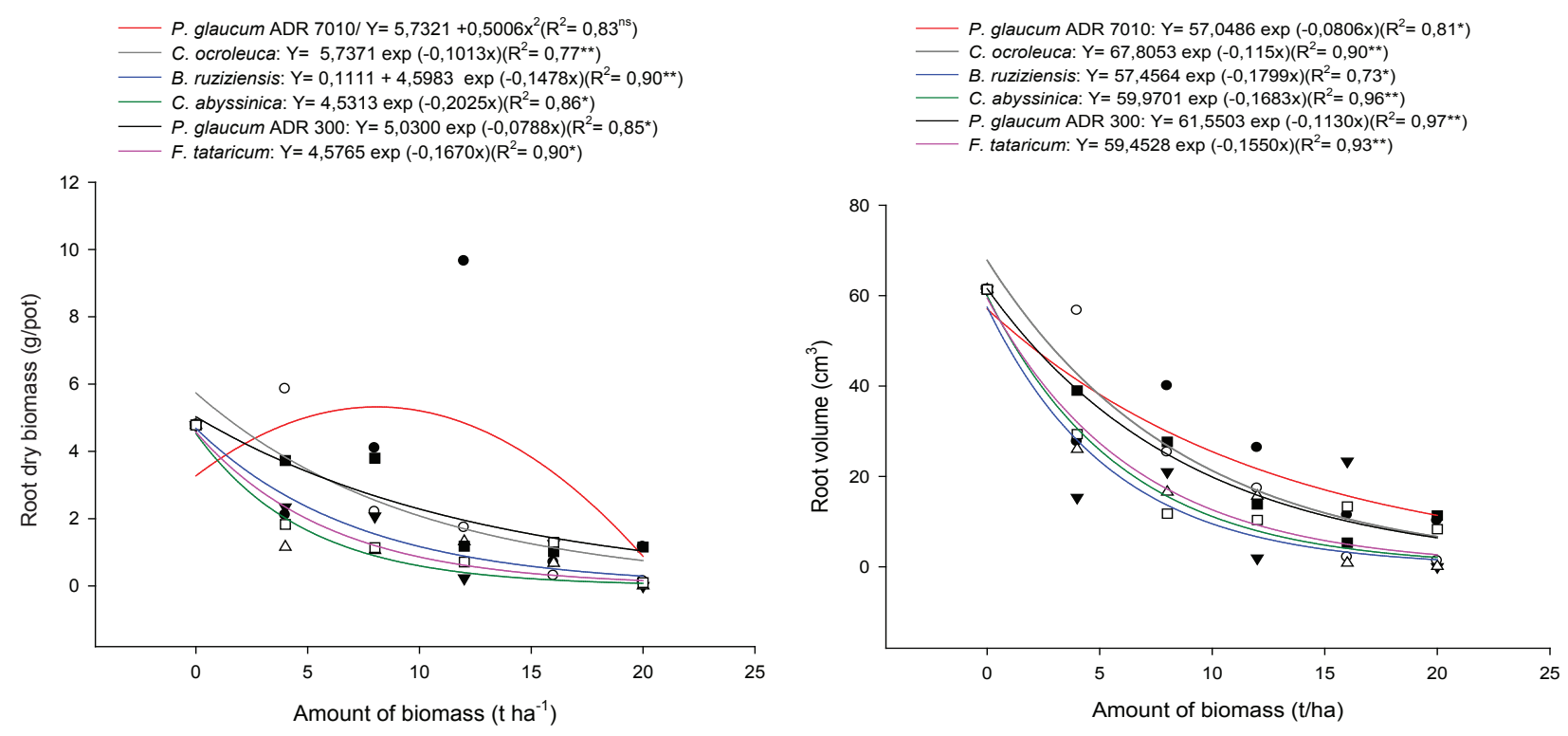

Figure 3. Root dry biomass and root volume of Bidens pilosa, according to the cover crop and amount of biomass. ${ }^{\text {ns }}$, * and ${ }^{* *}$ : not significant and significant at $\mathrm{p} \leq 0.1$ and $\mathrm{p} \leq 0.05$, respectively (Bom Jesus, PI, 2012).

leaf tissues was less efficient in intercepting solar radiation and preventing the emergence of $B$. pilosa seedlings. So, it was possible to conclude that the type of residue, even in similar amounts, showed different results for the weed species.

The RDB and RV of cover crops presented an exponential decrease, except for $P$. glaucum cv. ADR 7010, with more expressive reduction for the amount of initial biomass on the soil surface. These results demonstrate that, when using $8.0 \mathrm{t} \mathrm{ha}^{-1}$, there is a reduction of more than $50 \%$ in these variables, when compared to the control, whereas the cover with $C$. abyssinica and $F$. tataricum resulted, respectively, in the lowest root dry biomass and root volume averages (Figure 3). Moraes et al. (2010) found similar values for the RDB of Bidens pilosa covered with arrowleaf clover, at $6.0 \mathrm{t} \mathrm{ha}^{-1}$ of dry biomass maintained on the soil surface.

Ferreira et al. (2007) pointed out that the Pinus elliottii extract caused no allelopathic effect on beggar's-tick, but that the eucalyptus extract significantly reduced the beggar's-tick germination speed index. Fortes et al. (2009) observed that the use of elderberry (Sambucus australis) and lemon grass (Cymbopogon citratus) hot water extract affected the average length of $B$. pilosa roots, enhancing its effect in accordance with the concentration increase.

\section{CONCLUSIONS}

1. The control technique with Urochloa ruziziensis and Fagopyrum tataricum cover crops showed significant reduction in the population density of Bidens pilosa, in different amounts of biomass.

2. Amounts between $4.0 \mathrm{t} \mathrm{ha}^{-1}$ and $8.0 \mathrm{t} \mathrm{ha}^{-1}$ of dry biomass cover crops were sufficient to promote significant reduction in the emergence and growth of Bidens pilosa.

\section{REFERÊNCIAS}

ALVARENGA, R. C. et al. Plantas de cobertura de solo para sistema plantio direto. Informe Agropecuário, Belo Horizonte, v. 22, n. 1, p. 25-36, 2001.

AMARAL, A.; TAKAKI, M. Achene dimorphism in Bidens pilosa $\mathrm{L}$. as determined by germination test. Brazilian Archives of Biology and Technology, Curitiba, v. 41, n. 1, p. 11-16, 1998.

BASSO, S. M. S. Caracterização morfológica e fixação biológica de nitrogênio de espécies de Adesmia DC e Lotus L. 1999. 268 f. Tese (Doutorado em Zootecnia) Universidade Federal do Rio Grande do Sul, Porto Alegre, 1999.

CHAUHAN, B. S.; SINGH, R. G.; MAHAJAN, G. Ecology and management of weeds under conservation agriculture: a review. Crop Protection, Amsterdam, v. 38, n. 1, p. 57-65, 2012. 
CHIVINGE, O. A. Studies on the germination and seedling emergence of Bidens pilosa and its response to fertilizer application. Transactions of the Zimbabwe Scientific Association, Bulawayo, v. 70, n. 1, p. 1-5, 1996.

COMPANHIA NACIONAL DE ABASTECIMENTO (Conab). $6^{\circ}$ levantamento da produção de grãos: safra 2011/12. Brasília, DF: Conab, 2012.

CORREIA, N. M.; DURIGAN, J. C.; KLINK, U. P. Influência do tipo e da quantidade de resíduos vegetais na emergência de plantas daninhas. Planta Daninha, Viçosa, v. 24, n. 2, p. 245-253, 2006.

ERASMO, E. A. L. et al. Potencial de espécies utilizadas como adubo verde no manejo integrado de plantas daninhas. Planta Daninha, Viçosa, v. 22, n. 3, p. 337342, 2004.

FERREIRA, M. C.; SOUZA, J. R. P.; FARIA, T. J. Potenciação alelopática de extratos vegetais na germinação e no crescimento inicial de picão-preto e alface. Ciência e Agrotecnologia, Lavras, v. 31, n. 4, p. 1054-1060, 2007.

FORTES, A. M. T. et al. Efeito alelopático de sabugueiro e capim-limão na germinação de picão-preto e soja. Acta Scientiarum Agronomy, Maringá, v. 31, n. 2, p. 241-246, 2009.

GIMENES, M. J. et al. Interferência da Urochloa Decumbens Stapf. sobre plantas daninhas em sistema de consórcio com o milho. Revista Caatinga, Angicos, v. 24, n. 3, p. 215-220, 2011.

KISSMANN, K. G. Plantas daninhas e nocivas. 2. ed. São Bernardo do Campo: Basf, 1997.

KISSMANN, K. G.; GROTH, D. Plantas infestantes e nocivas. São Paulo: Basf, 1992.

KLEIN, A.; FELLIPE, G. M. Efeitos da luz na germinação de sementes de ervas invasoras. Pesquisa Agropecuária Brasileira, Brasília, DF, v. 26, n. 7, p. 955-966, 1991.
MAGUIRE, J. D. Speed of germination-aid in selection evaluation for seedling emergence and vigour. Crop Science, Madison, v. 2, n. 2, p. 176-199, 1962.

MORAES, P. V. D. et al. Efeito alelopático de plantas de cobertura, na superfície ou incorporadas ao solo, no controle de picão-preto. Revista da FZVA, Porto Alegre, v. 17, n. 1, p. 51-67, 2010.

PACHECO, L. P. et al. Produção de fitomassa e acúmulo e liberação de nutrientes por plantas de cobertura na safrinha. Pesquisa Agropecuária Brasileira, Brasília, DF, v. 46, n. 1, p. 17-25, 2011.

PACHECO, L. P. et al. Sobressemeadura da soja como técnica para supressão da emergência de plantas daninhas. Planta Daninha, Viçosa, v. 27, n. 3, p. 455-463, 2009.

QUEIROZ, L. R. et al. Supressão de plantas daninhas e produção de milho-verde orgânico em sistema de plantio direto. Planta Daninha, Viçosa, v. 28, n. 2, p. 263-270, 2010.

SEVERINO, F. J.; CHRISTOFOLETTI, P. J. Efeito de quantidades de fitomassa de adubos verdes na supressão de plantas daninhas. Planta Daninha, Viçosa, v. 19, n. 2, p. 223-228, 2001.

SILVA, J. et al. Alelopatia de Camelina sativa Boiss. (Brassicaceae) sobre a germinação e desenvolvimento inicial de Bidens pilosa (L.) e Glycine max (L.) Merr. Revista Biotemas, São Carlos, v. 24, n. 4, p. 17-24, 2011.

THEISEN, G.; VIDAL, R. A.; FLECK, N. G. Redução da infestação de Urochloa plantaginea em soja pela cobertura do solo com palha de aveia-preta. Pesquisa Agropecuária Brasileira, Brasília, DF, v. 35, n. 4, p. 753-756, 2000.

TREZZI, M. M.; VIDAL, R. A. Potencial de utilização de cobertura vegetal de sorgo e milheto na supressão de plantas daninhas em condições de campo: II. Efeitos de cobertura morta. Planta Daninha, Viçosa, v. 22, n. 1, p. 1-10, 2004. 